2016

\title{
Ceramics at Three Ancestral Caddo Sites in the Upper Neches River Basin, Smith County, Texas
}

Timothy K. Perttula

Heritage Research Center, Stephen F. Austin State University

Follow this and additional works at: https://scholarworks.sfasu.edu/ita

Part of the American Material Culture Commons, Archaeological Anthropology Commons, Environmental Studies Commons, Other American Studies Commons, Other Arts and Humanities Commons, Other History of Art, Architecture, and Archaeology Commons, and the United States History Commons

Tell us how this article helped you.

This Article is brought to you for free and open access by the Center for Regional Heritage Research at SFA ScholarWorks. It has been accepted for inclusion in Index of Texas Archaeology: Open Access Gray Literature from the Lone Star State by an authorized editor of SFA ScholarWorks. For more information, please contact cdsscholarworks@sfasu.edu. 
Ceramics at Three Ancestral Caddo Sites in the Upper Neches River Basin, Smith County, Texas

\section{Creative Commons License}

\section{(c) (i) (9)}

This work is licensed under a Creative Commons Attribution-NonCommercial 4.0 International License 


\title{
Ceramics at Three Ancestral Caddo Sites in the Upper Neches River Basin, Smith County, Texas
}

\author{
Timothy K. Perttula
}

\begin{abstract}
Introduction
The upper Neches River Basin in the Pineywoods and Post Oak Savannah of East Texas is one part of the southern Caddo area where populations of ancestral Caddo groups were notably higher during the Late Caddo period, ca. A.D. 1400-1680, than at other times over their ca. 1000 year settlement of the region. The Frankston phase is comprised of farmsteads, hamlets, and small villages in the Neches and Angelina river basins in East Texas. Other Frankston phase sites are represented by small residential settlements in dispersed agricultural communities, with small family and/or community cemeteries not used for long periods of time, such as at the Lang Pasture site (41AN38) (Perttula et al. 2011). Concentrations of Frankston phase sites in the upper Neches River basin seem to comprise base settlement clusters with middens, burials, and house structures, likely representing permanent settlements on streamside flats with fertile soils in the uplands. Other site types include scattered sherds, which perhaps are gathering stations in which pitted stones are found with a few sherds, and small campsites. The ceramic vessel sherds from three Frankston phase settlements in the upper Neches River basin are the subject of this article.
\end{abstract}

\section{The Sites}

Caddo ceramic vessel sherds were recovered at 41SM87, 41SM89, and 41SM90 during the 1957 survey of Blackburn Reservoir (Johnson 1961), now known as Lake Palestine (Figure 1). During this survey, which was accomplished only through pedestrian survey and the gathering of artifacts visible on the surface in plowed fields and eroded areas, a large and diverse assemblage of Caddo ceramics were recovered by Johnson (1961). These artifacts are presently curated at the Texas Archeological Research Laboratory at The University of Texas at Austin.

The three sites are in landform settings east of and overlooking the Neches River floodplain in the middle and upper part of Lake Palestine (see Johnson 1961:Figure 1). 41SM87 covered 5.0 acres and had a midden deposit that reached to ca. $30 \mathrm{~cm}$ bs (Johnson 1961:227). 41SM89 was "situated on the floodplain of a small unnamed creek which flows into the Neches from the east" (Johnson 1961:229). This site also had midden deposits, although these reached to ca. $60 \mathrm{~cm}$ bs. $41 \mathrm{SM} 90$ was a settlement that extended over ca. 2.0 acres in a cultivated field.

Three Frankston phase burials were excavated at 41SM90 by members of the East Texas Archeological Society in the mid-1950s. The burials were laid out in an extended supine position with the heads of the deceased facing west (Johnson 1961:229), and this is a common burial orientation in upper Neches River basin Caddo cemeteries. Funerary offerings placed with the burials included eight ceramic vessels - three Poynor Engraved bottles, thee Hood Engraved effigy bowls, and two Poynor Engraved carinated bowls - as well as an engraved elbow pipe and 12 Perdiz arrow points (Johnson 1961:230).

\section{$41 S M 87$}

The ceramic vessel sherd collection at TARL that was gathered at 41SM87 during the 1957 archaeological survey includes 395 sherds from plain ware, utility ware, and fine ware vessels (Table 1). More 


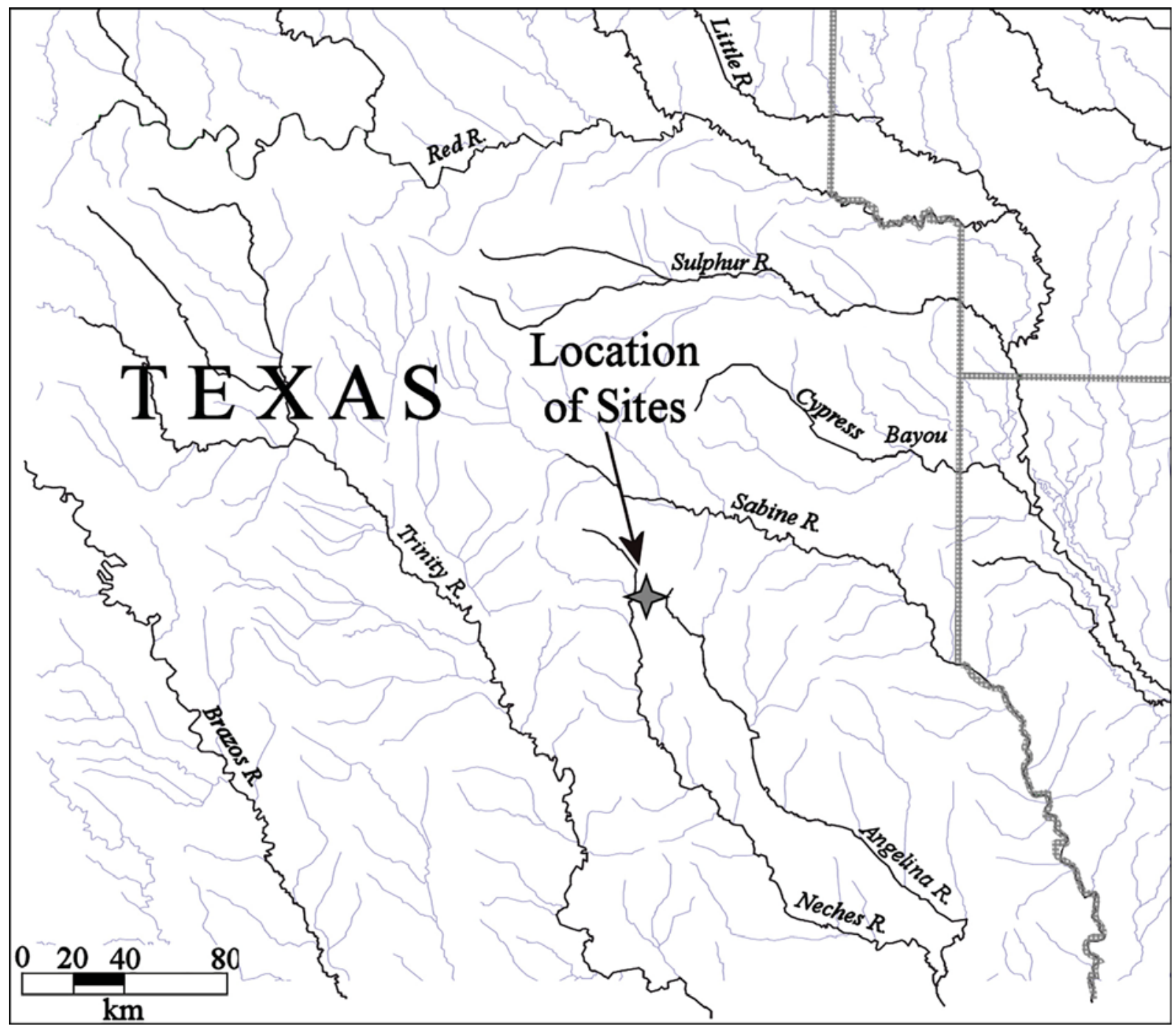

Figure 1. Location of ancestral Caddo sites discussed in this article.

than 98 percent of the sherds are from grog-tempered vessels, and bone-tempered vessels are represented only in the plain ware and utility ware sherds. One of the plain rim sherds has a scalloped lip.

Table 1. Ceramic wares from 41 SM87.

\begin{tabular}{lccl}
\hline Ware & Grog-tempered & Bone-tempered & N \\
\hline Plain & 215 & 4 & 219 \\
Utility & 149 & 3 & 152 \\
Fine & 24 & - & 24 \\
\hline Totals & 388 & 7 & 395
\end{tabular}

The plain to decorated sherd ratio is 1.24 , and about 87 percent of the decorated sherds in the 41SM87 assemblage are from utility ware vessels. The most common decorative method in the sherds is brushing (Table 2), and the many brushed, brushed-incised, and brushed-punctated sherds (56.2 percent 
of all the decorated sherds and 65.1 percent of the utility ware sherds) are almost all from Bullard Brushed jars. One Maydelle Incised sherd has diagonal opposed incised lines above an area of horizontal brushing marks (Figure 2a). Other Maydelle Incised sherds have cross-hatched, diagonal, and diagonal opposed lines on the rim panel, and several has diagonal incised zones filled with diagonal hatched lines (Figure 2b).

Table 2. Decorative methods and decorative elements in the utility ware and fine ware sherds from $41 \mathrm{SM87.}$

\begin{tabular}{llll}
\hline Decorative method and elements & Rim & Body & $\mathrm{N}$ \\
\hline Utility Ware & & &
\end{tabular}

\section{Brushed}

horizontal brushing marks

opposed brushing marks

overlapping brushing marks

parallel brushing marks

$\begin{array}{lll}1 & - & 1 \\ - & 3 & 3 \\ - & 5 & 5 \\ - & 83 & 83\end{array}$

\section{Brushed-Incised}

horizontal brushing marks and overlying cross-

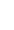

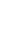

hatched incised lines and horizontal line under

the lip

parallel brushed-incised marks and lines

diagonal opposed incised el. above horizontal

brushing marks

\section{Brushed-Punctated}

horizontal brushing marks with tool punctated rows through the brushing

horizontal brushing marks (lower rim) - tool punctated

row at rim-body juncture-vertical brushing marks on body

parallel brushing marks and tool punctated rows pushed through the brushing

\section{Incised}

concentric curvilinear incised lines

cross-hatched incised lines

diagonal incised lines

diagonal incised zone with hatched lines

diagonal opposed incised lines

opposed incised lines

parallel incised lines

semi-circular incised line el.

straight incised line

\section{1}

\section{Incised-Punctated}

horizontal incised line below lip and rows of triangular tool punctations

horizontal and triangular incised lines and tool punctate-filled triangular incised zone 
Table 2. Decorative methods and decorative elements in the utility ware and fine ware sherds from 41SM87, cont.

\begin{tabular}{llll}
\hline Decorative method and elements & Rim & Body & $\mathrm{N}$ \\
\hline Utility Ware, cont. & & & \\
Punctated & & & 4 \\
fingernail punctated rows & - & 4 & 5 \\
tool punctated rows & 1 & 4 & 5
\end{tabular}

\section{Fine Ware}

\section{Engraved}

engraved bracket and triangle el. with diagonal hatched lines

concentric semi-circles and open bracket and triangle el.

circular engraved el.

curvilinear engraved lines

curvilinear engraved lines and diagonal hatched el.

horizontal engraved line beneath the lip

horizontal engraved line above carina

horizontal and vertical-curvilinear engraved lines

horizontal and diagonal engraved lines

parallel engraved lines

straight engraved line

straight engraved line and diagonal tick marks

triangle element with curvilinear hatched corners

triangle el. filled with diagonal hatched lines

$\begin{array}{lll}1 & - & 1 \\ - & 1 & 1 \\ - & 2 & 2 \\ - & 1 & 1 \\ - & 2 & 2 \\ 2 & - & 2 \\ - & 1 & 1 \\ 1 & - & 1 \\ - & 3 & 3 \\ - & 1 & 1 \\ - & 3 & 3 \\ - & 1 & 1 \\ - & 1 & 3 \\ - & 3 & \end{array}$

\section{Red Slipped}

ext. red-slipped$$
1
$$

2

\begin{tabular}{llll}
\hline Totals & - & 1 & 1 \\
\hline
\end{tabular}

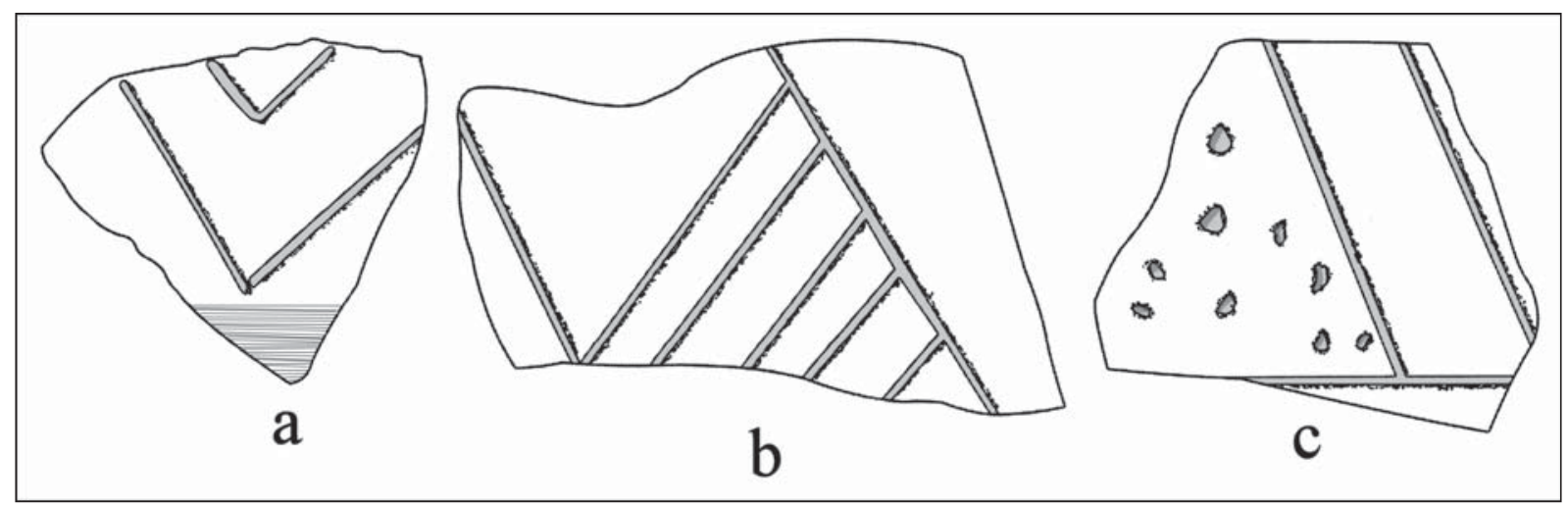

Figure 2. Selected decorative elements on utility ware sherds from 41SM87.

One of the incised-punctated sherds from 41SM87 is from a Maydelle Incised vessel. This sherd has triangular incised elements and associated diagonal incised lines, and the triangular elements are filled with tool punctations (see Figure 2c). The other incised-punctated sherd has at least six rows of tool 
punctations on the rim below a single horizontal incised line beneath the lip (see Table 2). The remainder of the utility wares have either rows of fingernail or tool punctations (5.9 percent of the utility wares).

The fine wares from 41SM87 are dominated by sherds from Poynor Engraved vessels. These sherds have triangle elements with diagonal or curvilinear hatched corners (Figure 3a, e-g), engraved brackets (Figure 3b-c), and concentric semi-circle elements (Figure 3d). One of the fine ware sherds has an exterior red slip (see Table 2).

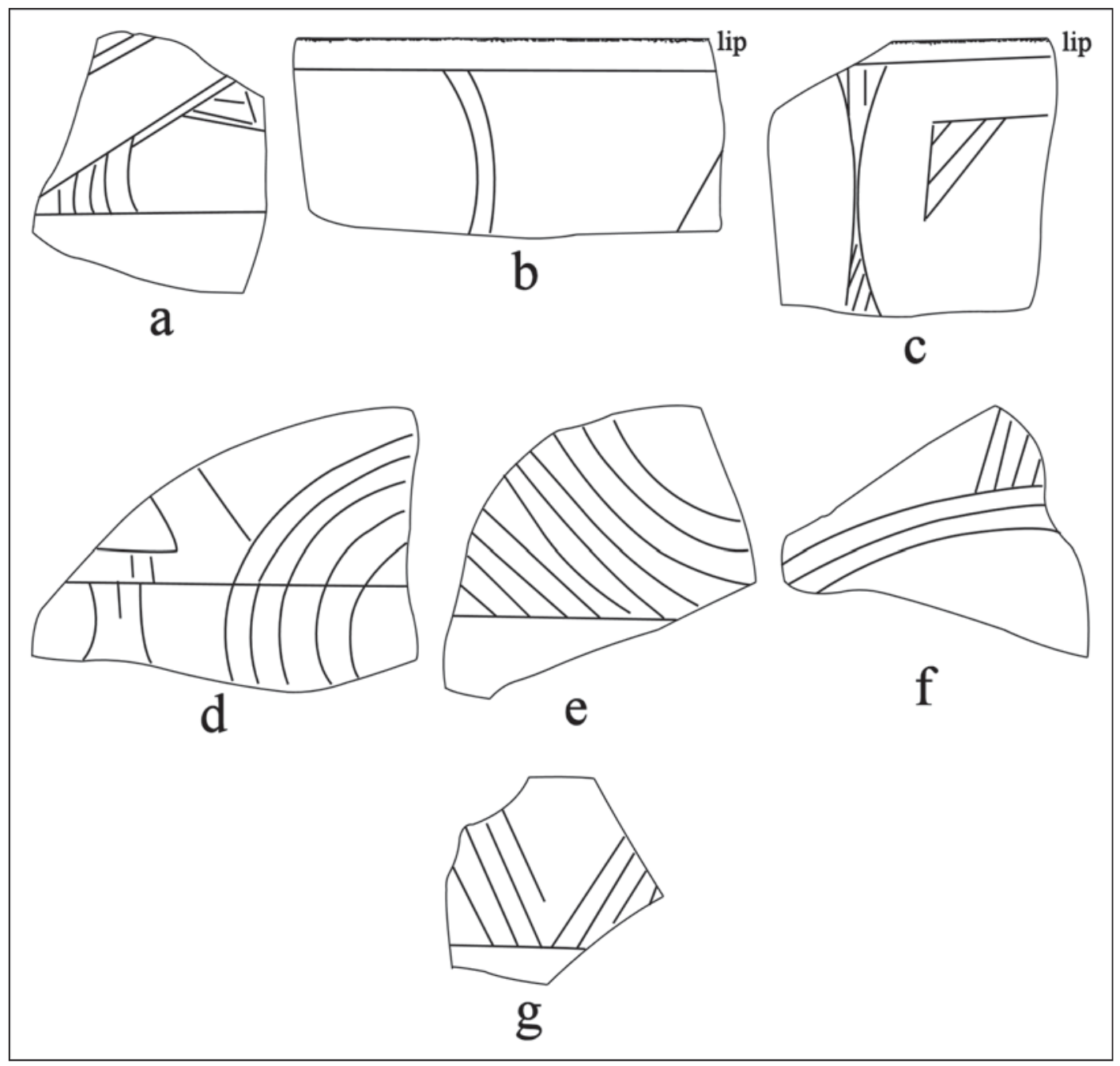

Figure 3. Selected decorative elements on Poynor Engraved sherds from 41SM87.

The proportion of brushed or wet paste sherds in the 41SM87 assemblage is key in determining when this upper Neches River basin was occupied. That proportion (56.2 percent), as well as the plain to decorated sherd ratio of 1.24, and the common occurrence of Poynor Engraved sherds, all indicate that the ancestral Caddo settlement at the site dates to the early part of the Frankston phase (ca. A.D. 1400-1480).

In addition to the ceramic vessel sherds, also in the collections is a plain pipe bowl rim, probably from a long-stemmed Red River pipe given the thickness of the bowl $(2.8 \mathrm{~mm})$.

Mark Walters provided a small sample of Caddo sherds ( $n=19)$ from 41SM87 that Mr. Sam Whiteside had collected. It is assumed that the sherds came from a surface collection, as did the UT collection, but it is not known when Mr. Whiteside obtained sherds from 41SM87 (Mark Walters, October 9, 2015 
personal communication). This collection of sherds are all from grog-tempered vessels. It includes two plain rim sherds (one with a lip tab), four plain body sherds, and three base sherds, and 10 decorated sherds from utility ware and fine ware vessels.

The utility ware sherds $(n=6)$ are from a Maydelle Incised jar with diagonal opposed incised lines $(\mathrm{n}=1)$ and Bullard Brushed vessels with parallel brushed $(\mathrm{n}=3)$, and vertical brushed-incised $(\mathrm{n}=1)$ decorative elements. One other utility ware sherd has a straight appliqued fillet.

All four of the fine ware sherds in the Whiteside collection from 41SM87 are from Poynor Engraved vessels, likely each carinated bowls. The first of the sherds is a rim from a Poynor Engraved, var. Cook vessel (see Perttula et al. 2011:Figure 6-64) with a diagonal engraved line across the rim panel and a curvilinear hatched triangle element at the juncture of the diagonal line and a single horizontal engraved line beneath the lip (Figure 4a). A second carinated bowl sherd is from a Poynor Engraved, var. E vessel that has a red slip on both interior and exterior vessel surfaces as well as a scroll and circle motif. The circle element is outlined by a number of excised triangle or ray elements (Figure $4 \mathrm{~b}$ ). A lower scroll element on this sherd is a large excised triangular-shaped element with excised corners.

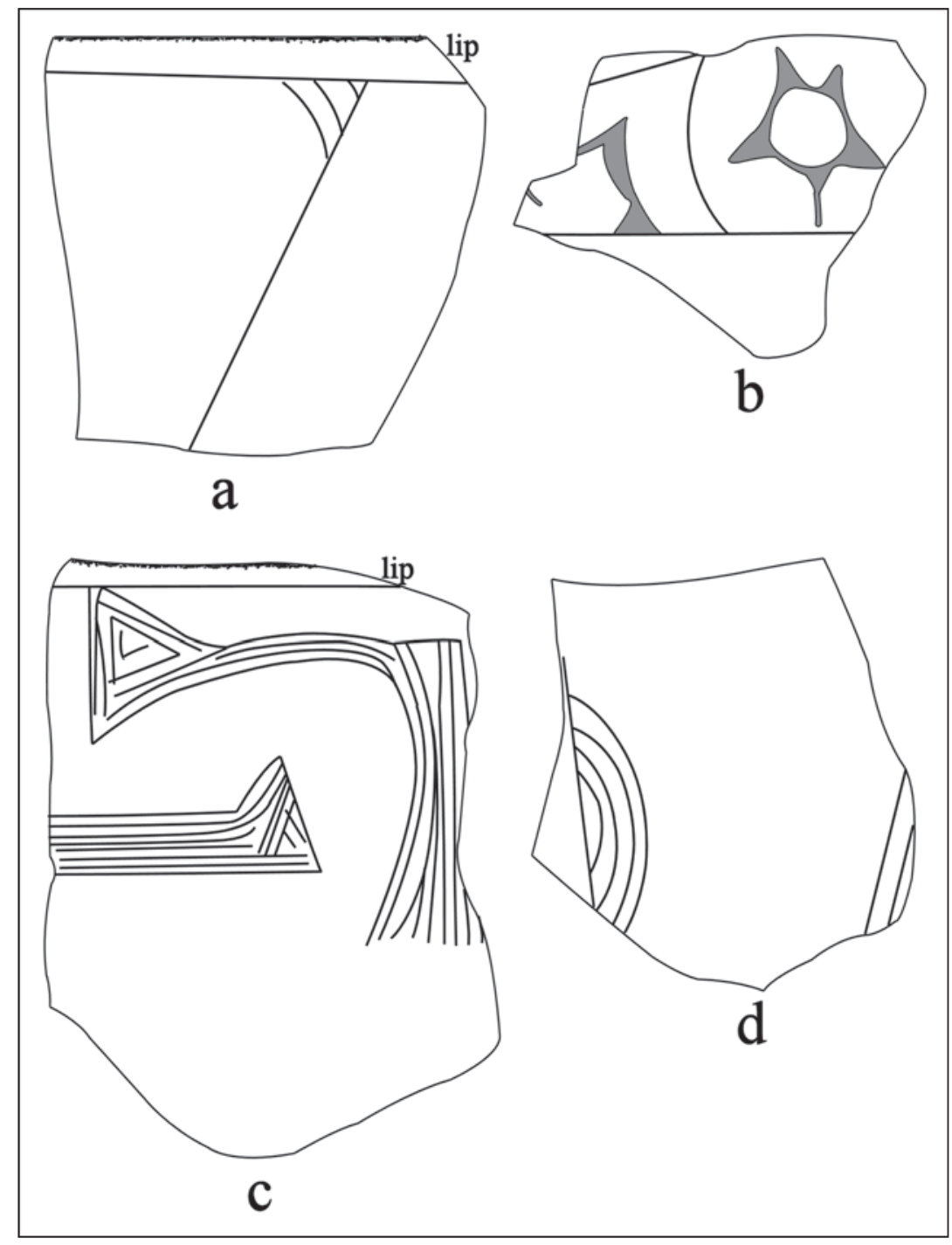

Figure 4. Decorative elements on Poynor Engraved sherds in the Sam Whiteside collection from 41SM87. 
A third Poynor Engraved sherd is from a regional variety var. $B$ vessel that has part of an interlocking and closely hatched horizontal and vertical scroll motif (see Figure 4c) on the rim panel, and the interlocking scrolls end in triangular-shaped hatched elements. The last of the Poynor Engraved sherds (Poynor Engraved, var. $R$ ) in the Whiteside collection has engraved concentric semi-circles (see Figure 4d).

\section{$41 S M 89$}

There are 402 sherds in the 41SM89 assemblage from plain, utility, and fine ware vessels (Table 3). Approximately 10.5 percent of the sherds are from bone-tempered vessels, particularly among the fine wares (13.3 percent).

Table 3. Ceramic wares from 41SM89.

\begin{tabular}{lccc}
\hline Ware & Grog-tempered & Bone-tempered & $\mathrm{N}$ \\
\hline Plain & 234 & 32 & 266 \\
Utility & 100 & 6 & 106 \\
Fine & 26 & 4 & 30 \\
\hline Totals & 360 & 42 & 402 \\
\hline
\end{tabular}

The 136 decorated sherds in the assemblage from 41SM89 are dominated by utility wares (77.9 percent); the plain to decorated sherd ratio us 1.96. Sherds from brushed, brushed-incised, and brushedpunctated vessels comprise 39.0 percent of the decorated sherds in the assemblage (and 50 percent of the utility ware sherds), and sherds with incised decorative elements represent 26.5 percent of the 41SM89 decorated sherds (and 34.0 percent of the utility ware sherds, Table 4). Cross-hatched incised decorative elements (Figure 5a) on Maydelle Incised jars are the most common incised element in the assemblage.

Table 4. Decorative methods and decorative elements in the utility ware and fine ware sherds from 41SM89.

\begin{tabular}{llll}
\hline Decorative method and elements & Rim & Body & $\mathrm{N}$ \\
\hline
\end{tabular}

Utility Ware

\section{Brushed}

horizontal brushing marks

opposed brushing marks

overlapping brushing marks

parallel brushing marks

vertical brushing marks

Brushed-Incised

parallel brushed-incised marks and lines

parallel brushing marks and overlying parallel incised lines

\section{Brushed-Punctated}

diagonal brushing marks and tool punctated row pushed through the brushing horizontal brushing marks above tool punctated row parallel brushing marks and tool punctated rows pushed through the brushing 
Table 4. Decorative methods and decorative elements in the utility ware and fine ware sherds from 41SM89, cont.

\begin{tabular}{llll}
\hline Decorative method and elements & Rim & Body & $N$ \\
\hline Utility Ware, cont. & &
\end{tabular}

\section{Incised}

cross-hatched incised lines

diagonal incised lines

diagonal opposed incised lines

horizontal and cross-hatched incised lines

parallel incised lines

vertical and diagonal incised lines

$\begin{array}{lll}1 & 10 & 11 \\ 3 & - & 3 \\ - & 3 & 3 \\ - & 1 & 1 \\ - & 17 & 17 \\ 1 & - & 1 \\ - & & \\ - & 1 & 1 \\ - & 2 & 2 \\ & 1 & 1 \\ - & & \\ & 2 & 2 \\ - & & 1 \\ 1 & 1 & \end{array}$

\section{Incised-Punctated}

diagonal incised lines and adjacent tool punctated row parallel incised lines and adjacent tool punctated row straight incised line and adjacent tool punctated row

\section{Pinched}

curvilinear pinched ridges

\section{Punctated}

fingernail punctated rows

tool punctated rows

Fine Ware

\section{Engraved}

\section{circle el.}

circle el. with hatched pendant triangle el.

cross-hatched engraved lines

cross-hatched engraved zone

curvilinear engraved lines

curvilinear hatched triangle el.

diagonal opposed engraved lines*

hatched triangle el.

hatched triangle and circle el.

horizontal and diagonal engraved lines

horizontal and vertical zone with hatched lines

parallel engraved lines

parallel and straight lines

semi-circle el. and curvilinear hatched zone

straight engraved line

\begin{tabular}{|c|c|c|}
\hline - & 1 & 1 \\
\hline - & 2 & 2 \\
\hline 1 & - & 1 \\
\hline - & 1 & 1 \\
\hline - & 5 & 5 \\
\hline - & 1 & 1 \\
\hline - & 1 & 1 \\
\hline - & 4 & 4 \\
\hline - & 1 & 1 \\
\hline - & 1 & 1 \\
\hline - & 1 & 1 \\
\hline - & 3 & 3 \\
\hline - & 1 & 1 \\
\hline - & 1 & 1 \\
\hline - & 1 & 1 \\
\hline - & 1 & 1 \\
\hline - & 3 & 3 \\
\hline - & 1 & 1 \\
\hline 10 & 126 & 136 \\
\hline
\end{tabular}

\section{Engraved-Punctated}

hatched curvilinear zone and curvilinear zone with excised circular punctations

\section{Red-Slipped}

ext. red-slipped*

\section{Red-Slipped-Appliqued}

ext. red-slipped and row of appliqued nodes

*bottle sherds 


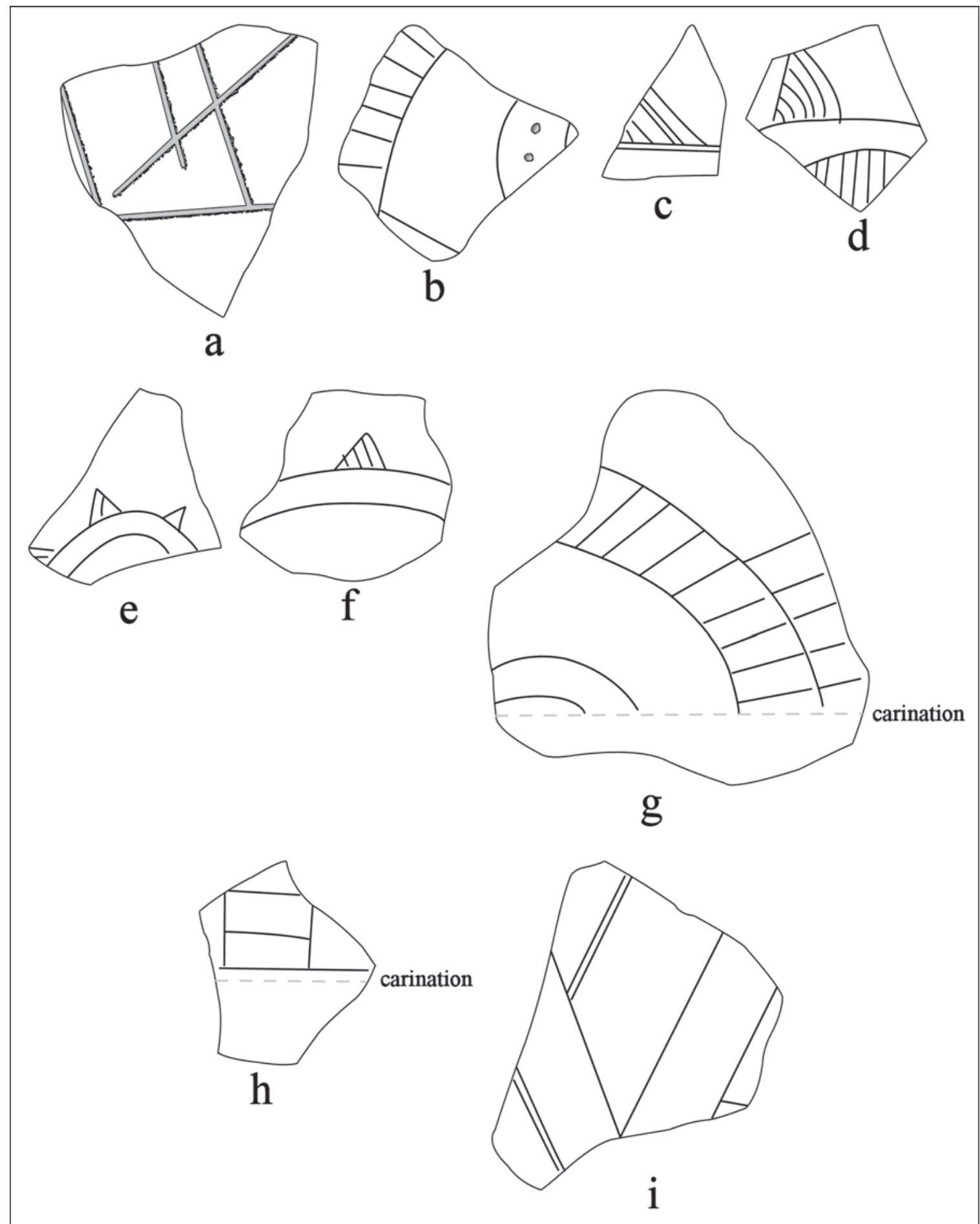

Figure 5. Selected decorative elements on utility ware and fine ware sherds from 41SM89.

Other utility wares at 41SM89 include sherds with incised-punctated (2.9 percent of the decorated sherds), pinched (1.5 percent of the decorated sherds), and punctated (8.1 percent of the decorated sherds) decorative elements. The pinched sherds are from Killough Pinched vessels (see Suhm and Jelks 1962:Plate 46). 
The engraved sherds from 41SM89 are from Poynor Engraved vessels that have distinctive triangle elements filled with diagonal or curvilinear hatched lines (see Figure 5c-d). Other sherds that are likely also from Poynor Engraved vessels have curvilinear engraved lines with hatched pendant triangles (see Figure 5e-f). One bottle sherd has diagonal opposed engraved lines (see Figure 5i), and two others have hatched zones: vertical hatching (see Figure 5h) or diagonal hatching in a curvilinear zone (see Figure 5g). Another engraved sherd in the 41SM89 assemblage has a curvilinear hatched zone adjacent to another curvilinear zone, and the zone is filled with a row of small excised circular punctations (see Figure $5 b$ ).

A distinctive characteristic of the fine ware sherds from 41SM89 is the occurrence and proportion of red-slipped sherds: they comprise 2.9 percent of the decorated sherds in the assemblage and 13.3 percent of the fine wares (see Table 4). The one red-slipped-appliqued sherd is likely from a Maxey Noded Redware vessel (see Suhm and Jelks 1962:Plate 51), more commonly seen as a fine ware in upper Sabine River and Red River Middle Caddo period assemblages.

The overall character of the decorated sherds from 41SM89, particularly the relative proportions of brushed and wet paste utility wares, suggests an ancestral Caddo occupation of the Frankston phase that dates from the early $15^{\text {th }}$ century (or even a settlement that began in the late $14^{\text {th }}$ century), perhaps contemporaneous with the Caddo occupation at the Lang Pasture site (41AN38) (see Perttula et al. 2011). At this site, red-slipped and engraved-punctated sherds comprise 4.9 percent of the fine wares (Perttula et al. 2011:Table 6-13) compared to 16.7 percent of the 41SM89 fine wares. The engraved-punctated sherds are likely from several varieties of Poynor Engraved (see Suhm and Jelks 1962:Plate 62g, i) where punctated zones are seen, and the Maxey Noded Redware sherd from 41SM89 is notable.

\section{SM90}

About 69 percent of the sherds from 41SM90 are plain wares (Table 5). Another 24.3 percent are sherds from utility ware vessels, and the remaining 7 percent are sherds from fine ware vessels. More than 97 percent of the sherds are from grog-tempered vessels; none of the fine ware sherds are from bone-tempered vessels.

Table 5. Ceramic wares from 41SM90.

\begin{tabular}{lccc}
\hline Ware & Grog-tempered & Bone-tempered & N \\
\hline Plain & 181 & 6 & 187 \\
Utility & 64 & 2 & 66 \\
Fine & 19 & - & 19 \\
\hline Totals & 264 & 8 & 272 \\
\hline
\end{tabular}

The 85 decorated sherds in the assemblage from 41SM90 are from utility ware (77.6 percent) and fine ware (22.4 percent) vessels. The plain to decorated sherd ratio is 2.20.

Most of the decorated sherds are from brushed, brushed-incised, and brushed-punctated Bullard Brushed vessels: these sherds comprise 50.6 percent of the decorated sherds in the 41SM90 assemblage and 65.2 percent of the utility wares (Table 6). Sherds from Maydelle Incised vessels account for another 20.0 percent of the decorated sherds. 
Table 6. Decorative methods and decorative elements in the utility ware and fine ware sherds from $41 \mathrm{SM90.}$

\begin{tabular}{llll}
\hline Decorative method and elements & Rim & Body & N
\end{tabular}

Utility Ware

\section{Brushed}

curvilinear brushing marks

opposed brushing marks

overlapping brushing marks

parallel brushing marks

\section{Brushed-Incised}

curvilinear incised line and adjacent parallel brushed

zone

diagonal opposed incised lines above horizontal

brushing

parallel brushing marks and overlying parallel

incised lines

\section{Brushed-Punctated}

parallel brushing marks and fingernail punctated rows pushed through the brushing

\section{Incised}

cross-hatched incised lines

curvilinear incised line

diagonal opposed incised lines

opposed incised lines

parallel incised lines

semi-circular incised lines

\section{Incised-Punctated}

parallel incised lines and adjacent fingernail punctates straight incised line and adjacent cane punctated rows straight incised line and adjacent tool punctated rows

$\begin{array}{lc}- & 1 \\ - & 1 \\ - & 1 \\ - & 36\end{array}$

\section{Punctated}

opposed fingernail punctated rows tool punctated rows

\section{Fine Ware}

\section{Engraved}

circle el. and excised pendant triangle el. cross-hatched engraved triangular zone curvilinear engraved lines curvilinear engraved lines and open pendant triangles* diagonal and curvilinear hatched zones horizontal engraved line beneath lip

$\begin{array}{lll}1 & 3 & 4 \\ - & 1 & 1 \\ - & 2 & 2 \\ - & 1 & 1 \\ - & 8 & 8 \\ - & 1 & 1 \\ & & \\ - & & 1 \\ - & 1 & 1 \\ - & 1 & 1 \\ & 1 & \\ - & & 1 \\ 1 & 1 & 2\end{array}$


Table 6. Decorative methods and decorative elements in the utility ware and fine ware sherds from 41SM90, cont.

\begin{tabular}{|c|c|c|c|}
\hline Decorative method and elements & Rim & Body & $\mathrm{N}$ \\
\hline \multicolumn{4}{|l|}{ Fine Ware, cont. } \\
\hline horizontal engraved line above carina & - & 1 & 1 \\
\hline horizontal engraved line and curvilinear engraved el. & - & 1 & 1 \\
\hline horizontal engraved line and hatched triangle el. & 1 & - & 1 \\
\hline $\begin{array}{l}\text { horizontal engraved lines and open and excised } \\
\text { pendant triangles* }\end{array}$ & - & 1 & 1 \\
\hline $\begin{array}{l}\text { horizontal-curvilinear engraved lines and hatched } \\
\text { diagonal zone* }\end{array}$ & - & 1 & 1 \\
\hline horizontal-diagonal engraved lines & - & 1 & 1 \\
\hline horizontal-vertical-diagonal lines and excised triangle el. & - & 1 & 1 \\
\hline straight engraved line & - & 3 & 3 \\
\hline \multicolumn{3}{|l|}{ Engraved-Punctated } & 1 \\
\hline $\begin{array}{l}\text { Red-Slipped } \\
\text { ext. red-slipped }\end{array}$ & - & 1 & 1 \\
\hline Totals & 5 & 80 & 85 \\
\hline
\end{tabular}

*bottle sherds

The remainder of the utility ware sherds at 41SM90 have incised-punctated (4.5 percent of the utility wares) and punctated (4.5 percent of the utility wares) decorative elements (see Table 6).

A fine ware rim sherd from 41SM90 has a bracket-shaped engraved zone filled with rows of small excised punctations (Figure 6a). Other engraved sherds are from Poynor Engraved vessels - likely carinated bowls - that have scroll lines and excised pendant triangles (Figure 6d), hatched triangle elements (Figure 6f), hatched triangle elements and diagonal opposed hatched curvilinear zones (Figure 6c), and closely-spaced curvilinear elements (Figure 6h). One rim sherd with hatched triangle elements has a scalloped rim and a lip tab (Figure 6f).

Another Poynor Engraved body sherd has an engraved circle or sun element with excised pendant triangles (see Figure 6b). This sherd is likely from a Poynor Engraved, var. Lang vessel (Perttula et al. 2011:Figure 6-64f). Poynor Engraved bottle sherds have large open or excised pendant triangle elements on sets of horizontal or curvilinear engraved lines (see Figure $6 \mathrm{~g}-\mathrm{h}$ ). One fine ware sherd has an exterior red slip (see Table 6).

The ceramic metrics of the 41SM90 decorated sherd assemblage-i.e., the plain to decorated sherd ratio, proportion of brushed sherds, proportion of wet paste sherds, and the ratio of brushed to wet paste sherds - are consistent with an early Frankston phase occupation (ca. A.D. 1400-1480) in the upper Neches River basin. In such sites a majority of the decorated sherds are from vessels with brushed decorative elements, but a considerable proportion of other wet paste sherds (i.e., incised, incised-punctated, punctated, pinched, etc.) are in the decorated sherd assemblages, and the principal fine ware is Poynor Engraved. Plain to decorated sherds in early Frankston phase assemblages in the upper Neches River basin range from 1.24-2.25. 


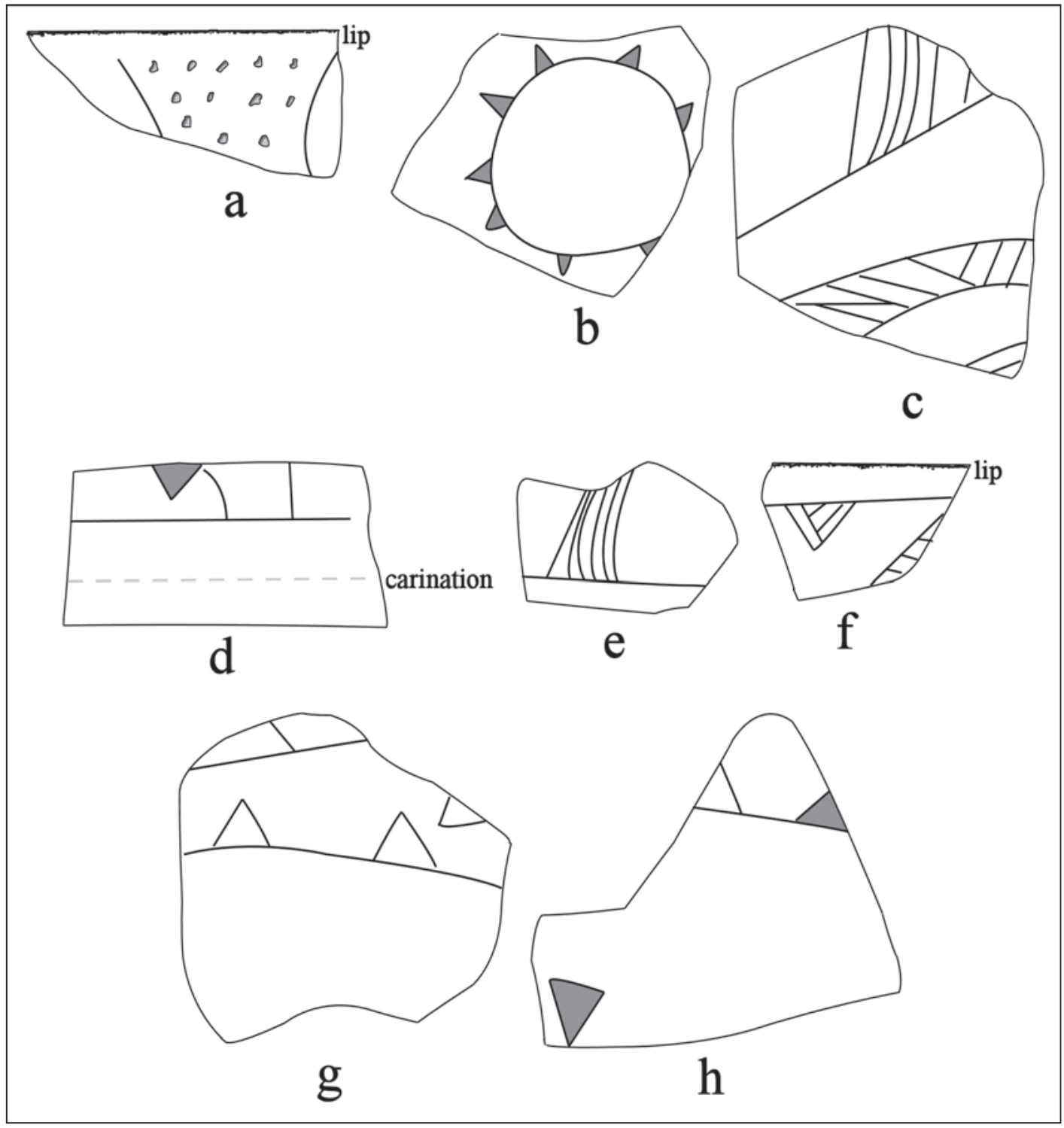

Figure 6. Selected decorative elements in fine ware sherds from 41SM90.

\section{Summary and Conclusions}

Ancestral Caddo Frankston phase sites are widely dispersed in the upper Neches River basin in East Texas, being found along many tributary streams as well as in the Neches River valley itself. Sites 41SM87, 41SM89, and 41SM90 are three such Frankston phase sites in the Neches River valley; they were identified and investigated in 1957 during the first archaeological survey of then proposed Blackburn Reservoir, now known as Lake Palestine.

Substantial Caddo ceramic vessel sherd collections of early Frankston phase age (ca. A.D. 14001480) were obtained from the three sites during the 1957 survey: between 272-402 sherds per site, and between 85-176 decorated sherds per site; a small collection of sherds provided by Mark Walters from 41SM87 has also been analyzed as part of this study. The three assemblages are dominated by sherds from grog-tempered vessels (ca. 90-98 percent of the sherds by site), and with considerable proportions of decorated sherds, many from utility ware vessels: plain to decorated sherd ratios on the three sites range from 1.24-2.20. On the three sites, between 39.0-56.2 percent of all the decorated sherds have 
brushed decorative elements, and almost all of these sherds are from Bullard Brushed jars. Other utility ware sherds are from Maydelle Incised and Killough Pinched vessels. Sherds from La Rue Neck Banded vessels are notable by their absence. The principal fine ware in the assemblages from 41SM87, 41SM89, and 41SM90 are Poynor Engraved bowls, carinated bowls, and bottles. These Frankston phase ceramic assemblages are distinctive in that in addition to engraved fine wares, there are sherds from engravedpunctated vessels ( 0.5 percent of the decorated sherds from the three sites) as well as sherds from redslipped ( 1.3 percent of the decorated sherds from all three sites) and red-slipped-appliqued ( 0.3 percent of the decorated sherds from the three sites) vessels. The red-slipped-appliqued sherd from 41SM89 may be from a Maxey Noded Redware vessel.

\section{Acknowledgements}

Thanks to Marybeth Tomka at the Texas Archeological Research Laboratory at The University of Texas at Austin for facilitating access to the collections from these three ancestral Caddo sites. Mark Walters provided the sherds from 41SM87 for documentation that were earlier collected by Sam Whiteside. Lance Trask prepared the figures for this article.

\section{References Cited}

Johnson, L., Jr.

1961 An Archeological Survey of Blackburn Crossing Reservoir on the Upper Neches River. Bulletin of the Texas Archeological Society 31:213-238.

Perttula, T. K., D. B. Kelley, and R. A. Ricklis (assemblers and editors)

2011 Archeological Investigations at the Lang Pasture Site (41AN38) in the Upper Neches River Basin of East Texas. Report No. 129. Texas Department of Transportation, Archeological Studies Program, Environmental Affairs Division, Austin.

Suhm, D. A. and E. B. Jelks (editors)

1962 Handbook of Texas Archeology: Type Descriptions. Special Publication No. 1, Texas Archeological Society, and Bulletin No. 4, Texas Memorial Museum, Austin. Reprinted in 2009, Gustav's Library, Davenport, Iowa. 